\title{
Studi Kesukaan Sensoris Aplikasi Tepung Asap Cair Cangkang Sawit dan Optimasinya Pada Mie Goreng
}

\author{
Study of Sensory Preference Application of Palm Shell Liquid Smoke Flour and Its \\ Optimization in Fried Noodles
}

\author{
Edy Wibowo Kurniawan ${ }^{1 *}$, Evie Sophia ${ }^{2}$, Mujibu Rahman ${ }^{1}$ \\ ${ }^{1}$ Program Studi Teknologi Hasil Perkebunan, Politeknik Pertanian Negeri Samarinda. \\ ${ }^{2}$ Jurusan Teknologi Pengolahan Hasil Pertanian, Universitas Gadjah Mada, Jogjakarta.
}

*Corresponding author: edy_wibowosmd@yahoo.com

\begin{abstract}
Abstrak
Produk pangan bercitarasa bakar disukai masyarakat karena aroma dan rasanya yang khas. Agar lebih praktis memenuhi tuntutan zaman, tepung asap menjadi salah satu alternatif pengganti proses pengasapan. Tujuan dalam penelitian ini adalah untuk melakukan studi kesukaan secara sensoris dari aplikasi tepung asap cair cangkang kelapa sawit dan optimasinya pada mie goreng. Penelitian ini dilakukan pada dua tahap yaitu: a) produksi asap cair proses optimal dan redestilasinya, dilakukan dengan optimasi suhu pirolisis metode response surface methide (RSM), b) produksi dan aplikasi konsentrasi tepung asap 1$4 \%$ pada produk pangan. Dari redestilat asap cair di campur dengan maltodekstrin dengan beberapa perbandingan mulai $1: 1,2: 1,3: 1$, dan 4:1. Hasil penelitian menunjukkan bahwa cara produksi asap cair yang optimal dicapai dengan kadar air bahan 14,75\%, dalam waktu 4,57 menit, pada suhu $499,30{ }^{\circ} \mathrm{C}$, dengan kandungan fenol, karbonil dan asam berturut-turut $2,22 \% ; 2,13 \%$ dan $12,34 \%$. Bau asap yang paling disukai dihasilkan dengan redestilat asap cair: maltodekstrin (1: 1) dengan konsentrasi $1 \%$ dari tepung basis.
\end{abstract}

Kata Kunci: asap cair, cangkang kelapa sawit, tepung asap

\section{Abstract}

Grilled food products are liked by the public because of their distinctive aroma and taste. It's more practical to meet the demands of the times, smoked flour is an alternative to the smoking process. The purpose of this research is to study the sensory preference of the application palm kernel shell liquid smoked flour and its optimization on fried noodles. This research was carried out in two stages: a) the optimal process of liquid smoke production and its redestillation, carried out by optimizing the pyrolysis temperature response surface methode (RSM), b) production and application of 1-4\% smoked flour concentration in food products. From the liquid smoke redestilate mixed with maltodextrin in several ratios ranging from 1:1, 2:1, 3:1, and 4:1. The results showed that the optimal method of producing liquid smoke was achieved with a moisture content of $14.75 \%$, within 4.57 minutes, at a temperature of $499.30 \mathrm{C}$, with phenol, carbonyl and acid content respectively 2.22\%; $2.13 \%$ and $12.34 \%$. The most preferred smoke odor is produced by liquid smoke redistillate: maltodextrin (1: 1) with a concentration of $1 \%$ of flour base.

Keywords: Liquid smoke, palm oil shell, smokes flour.

\section{PENDAHULUAN}

Saat ini Kalimantan Timur, khususnya di Samarinda banyak sekali warung, kafe, supermarket maupun restoran yang menyediakan menu masakan asapan seperti : ikan bakar, daging panggang, sate, ayam bakar dan lain-lain. Pengasapan makanan merupakan salah satu cara pengolahan makanan yang menghasilkan citarasa, aroma dan warna khas pada produk yang dihasilkan dan digemari oleh masyarakat. Sebagian besar pengolahan produk asapan tersebut dengan cara tradisional.
Pengasapan tradisional dilakukan dengan cara membakar kayu, serbuk atau arang secara langsung sehingga memerlukan waktu yang lama, keseragaman produk untuk mendapatkan warna dan citarasa yang diinginkan sulit dikontrol serta menimbulkan pencemaran lingkungan maupun bahaya kebakaran.

Dengan adanya teknologi inovatif berbasis asap cair maka pemberian asap cair pada makanan akan lebih praktis karena hanya dengan mencelupkan atau merendam produk makanan tersebut ke dalam redestilat asap cair. Dengan demikian pengasapan 
dapat berlangsung dengan cepat, mudah dan terkontrol. Penggunaan asap cair lebih luas aplikasinya untuk menggantikan pengasapan makanan secara tradisional yang dilakukan secara manual yaitu bersama-sama dengan proses pemanasan (Darmadji, 1995).

Menurut Tomczyk dkk (2020), perkembangan asap cair semakin pesat karena mempunyai beberapa keunggulan antara lain : menghemat biaya yang dibutuhkan untuk kayu dan peralatan pengasapan, flavor produk lebih seragam, flavor lebih intensif dari pengasapan tradisional, flavor produk dapat diatur, komponen berbahaya dapat diatur sebelum diaplikasikan pada makanan, dapat diterapkan pada masyarakat awam, mengurangi pencemaran lingkungan.

Di sisi lain, Kalimantan Timur dengan produksi tandan buah segar 1,76 juta ton, akan menghasilkan limbah padat sebesar 1,3 juta ton/th. Bila diasumsikan limbah serat buah dipakai untuk bahan bakar boiler dan limbah inti dijual sebagai bahan kosmetik, maka terdapat potensi limbah padat berupa tandan kosong sebesar 361 ribu ton/th dan cangkang sawit sebesar 180 ribu ton/th (Kurniawan dkk, 2017).

Pada penelitian ini dilakukan pembuatan tepung asap dari cangkang sawit sebagai bumbu siap saji. Dengan pembuatan bumbu siap saji berupa tepung asap cair dari cangkang kelapa sawit akan memperkaya cita rasa dari produk yang dikonsumsi, dalam hal ini mie goreng. Saat ini mie goreng rasa bakar (barbeque) belum tersedia, padahal untuk produk makanan ringan sudah tersedia. Penggunaan tepung asap sangat mudah karena hanya dengan menaburkan pada produk makan diharapkan dapat memberikan cita rasa dan aroma khas produk asapan.

Tujuan penelitian ini adalah untuk memanfaatkan limbah cangkang sawit sebagai bahan baku dalam produksi tepung asap cangkang sawit pada produk mie goreng yang disukai oleh konsumen.

\section{BAHAN DAN METODE}

\section{Bahan dan Alat}

Bahan dasar penelitian berupa cangkang sawit dan bahan pembantu dalam pembuatan tepung asap, serta bahan kimia untuk pembuatan tepung asap dan analisa kimia. Bahan cangkang sawit diperolah dari PT Tritunggal Sentra Buana, Muara Badak,
Kutai Kartanegara. Sedangkan maltodektrin dari Brataco. Adapun peralatan yang digunakan meliputi : peralatan pirolisa pembuat asap cair, distilator untuk pemurnian asap cair, peralatan untuk analisa analisa kimia dan organoleptik.

\section{Prosedur Penelitian}

Penelitian dimulai dengan analisis proksimat cangkang kelapa sawit, pembuatan asap cair, pemurnian asap cair, pembuatan tepung asap, pembuatan mie goreng rasa asap, dan uji organoleptik. Penelitian dilakukan dengan rancangan percobaan acak lengkap faktorial dengan variasi konsentrasi tepung asap $(0 \%, 1 \%, 2 \%$, $3 \%, 4 \%$ ) pada produk mie goreng cita rasa asap. Analisa proksimat mengikuti SNI 063730-1995 (BSN, 1995) serta Speight, 2015.

\section{Pembuatan Asap Cair}

Cangkang sawit dimasukkan ke dalam reaktor pirolisator. Cangkang sawit sebanyak $4 \mathrm{~kg}$ dimasukkan ke dalam pirolisator, dengan volume pirolisator $5 \mathrm{~kg}$. Kemudian suhu diatur pada $500{ }^{\circ} \mathrm{C}$, proses pirolisa dilakukan selama 75 menit. Optimasi suhu pirolisa dilakukan dengan metode response surface methode (RSM) dengan software Design Expert 7.0 (Kurniawan, 2008). Pemurnian asap cair

Asap cair hasil pirolisa dimasukkan ke dalam labu distilasi dan dipanaskan menggunakan kompor listrik dengan media penangas oli. Pemanasan dilakukan pada fraksi suhu optimal, yaitu $101-125{ }^{\circ} \mathrm{C}$ (Kurniawan, 2008).

\section{Pembuatan Tepung Asap}

Campuran konsentrasi redistilat asap cair (RAC) : maltodesktrin yaitu: $1: 1 ; 2: 1$; $3: 1$; 4:1 dikeringkan pada suhu $70^{\circ} \mathrm{C}$ selama \pm 8 jam dengan kabinet drier.

Setelah campuran tersebut kering, kemudian digerus hingga lembut dengan mesin bender kering sehingga terbentuk Tepung asap. Tepung asap yang terbentuk dari berbagai campuran dianalisa uji organoleptik meliputi: kenampakan, warna, dan baul aroma. Campuran RAC: Maltodesktrin yang mempunyai intensitas tertinggi untuk parameter bau/ aroma dan dapat ditepungkan dijadikan sebagai tepung asap base. Tepung asap base yang terbentuk, diturunkan konsentrasinya dengan 
$1,2,3$, dan $4 \%$ dengan penambahan maltodekstrin. Hal ini sesuai dengan prosedur pembuatan tepung asap cair yang dikemukakan oleh (Pszczola, 1995) tentang keamanan pangan, terutama konsentrasi PAH direkomendasikan konsentrasi menjadi kurang dari 5\% terhadap distilat awal.

\section{Pembuatan Mie Goreng Cita Rasa Asap}

Mie kering direbus dengan air mendidih selama 3 menit sambil diaduk. Sementara mie dimasak, disiapkan sampuran bumbu, kecap manis dipiring. Mie ditiriskan Kemudian diaduk merata dengan campuran bumbu pada piring ditambah 3 tabur tepung asap pada tiap konsentrasi (1-4\%).

\section{Uji Organoleptik}

Uji organoleptik dilakukan untuk menilai tingkat kesukaan. Parameter yang diamati meliputi rasa, aroma dan kesukaan secara keseluruhan dengan skor 1-5 (sangat tidak disukai sampai sangat disukai). Pengujian sensoris menggunakan panelis tidak terlatih sebanyak 25 orang (Hardiaynti dkk, 2019).

\section{Parameter yang Diamati}

Parameter yang diamati meliputi analisa asap cair (meliputi analisa fenol menurut Kurniawan, 2008 dan analisa total asam menurut Sudarmadji dkk, 2007). Selain hal tersebut dilakukan uji organoleptik pada produk mie goreng cita rasa asap.

\section{HASIL DAN PEMBAHASAN}

\section{Analisa Proksimat Cangkang Sawit}

Hasil analisa proksimat kadar air, zat volatil, karbon terikat, dan kadar abu berturutturut sebesar $11,2 \%, 73,66 \%, 13,18 \%$, dan $1,96 \%$. Hasil analisa proksimat cangkang sawit ini mirip dengan yang dipaparkan oleh Kurniawan dkk (2019) seperti pada Tabel 1.

Dari hasil perbandingan analisa proksimat dengan referensi terlihat bahwa memberikan hasil yang mirip. Perbedaan yang kecil ini disebabkan varietas kelapa

Tabel 1. Analisa Proksimat Cangkang Sawit sawit dan keadaan bahan baku saat pengambilan sampel.

\section{Optimasi Produksi Asap Cair}

Menurut Kurniawan (2008), kondisi optimal produksi asap cair cangkang sawit diperkirakan berada pada kisaran 408,8$460{ }^{\circ} \mathrm{C}$, waktu $55,2-80$ menit, dan kadar air $11,00-15,8 \%$. Sedangkan titik untuk produksi asap cair cangkang sawit yang maksimal berada pada subu 499,3 C, waktu 74,57 menit, dan kadar air $14,75 \%$ dengan produksi maksimal sebesar $391,95 \mathrm{ml}$. Sedangkan arang minimum diperoleh pada suhu $437,2{ }^{\circ} \mathrm{C}$, waktu pirolisis 78,69 menit, kadar air bahan $13,21 \%$, dengan jumlah arang minimum 409,75 gram. Adapun endapan tar yang terbentuk maksimum diperoleh pada suhu $340{ }^{\circ} \mathrm{C}$, waktu pirolisis 65,52 menit, dan kadar air bahan cangkang sawit sebesar $11,54 \%$, dengan jumlah endapan tar maksimum sebesar $60,96 \mathrm{ml}$.

\section{Komposisi Kimia Asap Cair Cangkang Sawit}

Komposisi kimia asap cair cangkang sawit yang dihasilkan dari kondisi proses pirolisis dengan suhu pirolisis, waktu pirolisis, dan kadar air bahan pada perlakuan kondisi optimal yaitu : kadar senyawa fenol $(2,22 \%)$, karbonil $(2,13 \%)$, dan asam (12.34 \%).

Senyawa fenol dalam asap cair mempunyai peran dalam pembentukan aroma, citarasa dan wama pada asap cair. Jug mempunyai fungsi sebagai antibakteri dan antioksidan. Menurut Tranggono dkk (1996), kadar fenol yang dihasilkan pada tempurung kelapa sebesar 5,13\%. Kadar fenol yang dihasilkan sangat dipengaruhi oleh banyaknya senyawa lignin dan selulosa dalam cangkang sawit yang dipirolisa, di mana senyawa lignin dan selulosa merupakan senyawa penghasil fenol (Girard, 1992).

\begin{tabular}{ccc}
\hline Komponen & Hasil analisa cangkang sawit $(\%)$ & Referensi cangkang sawit $(\%)^{*}$ \\
\hline Kadar air & 11,20 & 10,81 \\
Zat volatil & 73,66 & 72,53 \\
Karbon terikat & 13,18 & 14,21 \\
Kadar abu & 1,96 & 2,45 \\
\hline
\end{tabular}

Keterangan : *Kurniawan dkk, 2019 
Senyawa karbonil dalam asap cair akan memberikan pengaruh utama pada pembentukan warma produk asapan. Kadar karbonil untuk tempurung kelapa seperti yang dikemukakan Tranggono dkk (1996), sebesar $13,28 \%$. Sedangkan kadar karbonil asap cair cangkang sawit sebesar 2,13\%, sehingga relatif lebih kecil dibanding asap cair tempurung kelapa. Senyawa karbonil pada asap cair dihasilkan dari pirolisis selulosa, dan sebagian berasal dari pirolisis hemiselulosa (Tomczyk dkk, 2020).

Penggunaan suhu tinggi pada proses pirolisis sebesar $499,33{ }^{\circ} \mathrm{C}$ menyebabkan kadar karbonil yang dihasilkan rendah(Lewandowski dkk, 2020). Hal ini sesuai dengan hasil penelitian Demirbas (2017), yang menyatakan bahwa peningkatan suhu darı $350-500{ }^{\circ} \mathrm{C}$ menyebabkan penurunan kadar karbonil. Kadar karbonil yang rendah akan meminimalkan resiko akan senyawa polisiklik aromatik hidrokarbon (PAH) yang merupakan senyawa karsinogenik.

Senyawa asam dalam asap cair dapat mempengaruhi flavor, $\mathrm{pH}$ dan umur simpan makanan (Pszczola, 1995). Dari hasil analisa asap cair cangkang sawit terlihat bahwa kadar asam yang diperoleh sebesar 12,34 \%. Sedangkan pada tempurung kelapa dilaporkan oleh Tranggono dkk (1996), kadar asam yang diperoleh sebesar 11,39\%. Kadar keasaman yang tinggi terjadi karena dekomposisi selulosa dan hemiselulosa terjadi secar maksimal dengan adanya waktu yang cukup sehingga kadar keasaman yang dihasilkan akan meningkat. Kandungan asam utama yang dihasilkan dalam asap cair adalah asam asetat dan homolognya. Asam tersebut dihasilkan dari proses pirolisa yang berlangsung dalam dua tahap. Tahap pertama yaitu reaksi hidrolisa selulosa menjadi $\beta$-glukosidase yang kemudian dialnjutkan dengan pirolisa menjadi asam, air furan dan fenol. Asam juga dihasilkan melalui proses pirolisa hemiselulosa di mana pada suhu 200 - $260{ }^{\circ} \mathrm{C}$ terjadi dekomposisi hemiselulosa menghasilkan metanol, asam asetat, dan asam lainnya (Husbands \& Cranford, 2019).

\section{Produksi Tepung Asap Cangkang Sawit \\ Penggunaan asap cair yang telah dimurnikan dengan cara redestilasi}

digunakan pada proses produksi tepung asap sebagai pemberi citarasa dan aroma khas asap dengan media pembawa (filler) maltodekstrin. Digunakannya maltodekstrin sebagai filler karena sifat maltodekstrin berupa padatan dengan kadar air yang rendah, dapat larut dalam air, kekentalan dekstrin yang relatif rendah sehingga memungkinkan dapat digunakan dalam proporsi yang tinggi dalam pengolahan pangan. Selain itu bahan pangan yang digunakan sebagai filler tidak boleh bereaksi dengan komponen yang akan diproses, hanya berikatan secar fisik sehingga pada saat tepung asap dilarutkan kembali maka komponen di dalamnya (fenol, karbonil, dan asam) masih memberikan sifat fungsional yang sama.

Proses pembuatan tepung asap mulamula dilakukan pencampuran antara redestilat asap cair $(\mathrm{ml})$ : maltodekstrin (gr) yaitu : 100:100 ; 200:100 ; 300:100 ; 400:100. Kemudian dilakukan pengeringan menggunakan kabinet drier pada suhu $70^{\circ} \mathrm{C}$ dengan waktu $8 \quad$ jam. Tujuan pengeringan pada suhu $70{ }^{\circ} \mathrm{C}$, karena pada suhu tersebut komponen sebyawa fenol, karbonil dan asam belum semuanya menguap sehingga kualitas produk asapan masih terjaga.

Pengeringan dihentikan setelah diperoleh kadar air tertentu yang ditandai dengan terbentuknya kristal kering. Kemudian dilakukan pengecilan ukuran dengan cara menggerus sampai lembut. Hasil analisa sensoris pada berbagai campuran RAC : maltodekstrin terlihat pada Tabel 2.

Dari Tabel 2. terlihat bahwa pada konsentrasi RAC : maltodekstrin 1:1 sampai 3:1 mudah ditepungkan dan bersifat higroskopis. Semakin tinggi campuran konsentrasi RAC : maltodekstrin (1:1 sampai 3:1), aroma yang dapat terdeteksi semakin kuat, sedangkan pada campuran 4:1, aromanya malah paling lemah karena campuran tersebut bersifat lengket, tidak dapat ditepungkan sehingga luas permukaan campuran jauh kebih kecil dibandingkan campuran lainnya yang berbentuk tepung. Campuran RAC : maltodekstrin 1:1 digunakan sebagai tepung base pada tahap selanjutnya. 
Tabel 2. Hasil Analisa sensoris tepung asap cangkang sawit

\begin{tabular}{|c|c|c|c|c|}
\hline $\begin{array}{c}\text { Konsentrasi } \\
\text { (RAC:maltodekstri } \\
\text { n) }\end{array}$ & $\begin{array}{c}\text { Bentu } \\
\text { k }\end{array}$ & Warna & $\begin{array}{c}\text { Tingkat } \\
\text { Higroskopis }\end{array}$ & Bau/Aroma \\
\hline $1: 1$ & $\begin{array}{c}\text { Tepun } \\
\mathrm{g}\end{array}$ & $\begin{array}{c}\text { Putih } \\
\text { Kecoklata } \\
\text { n } \\
+\end{array}$ & $\begin{array}{c}\text { Higroskopis } \\
+\end{array}$ & $\begin{array}{c}\text { Menyengat } \\
+\end{array}$ \\
\hline $2: 1$ & $\begin{array}{c}\text { Tepun } \\
\text { g }\end{array}$ & $\begin{array}{c}\text { Putih } \\
\text { Kecoklata } \\
\mathrm{n} \\
+++\end{array}$ & $\begin{array}{c}\text { Higroskopis } \\
++\end{array}$ & $\begin{array}{c}\text { Menyengat } \\
++\end{array}$ \\
\hline $3: 1$ & $\begin{array}{c}\text { Tepun } \\
\text { g }\end{array}$ & $\begin{array}{c}\text { Putih } \\
\text { Kecoklata } \\
n \\
+++\end{array}$ & $\begin{array}{c}\text { Higroskopis } \\
++++\end{array}$ & $\begin{array}{c}\text { Menyengat } \\
+++\end{array}$ \\
\hline $\left.4: 1^{*}\right)$ & $\begin{array}{c}\text { Kristal } \\
\text { lengke } \\
\mathrm{t}\end{array}$ & Coklat & Lengket & - \\
\hline
\end{tabular}

Keterangan:

$+=$ intensitas bertambah $\quad$ - = tidak dapat terdeteksi $\left.\quad{ }^{*}\right)=$ tidak terjadi penepungan

Tabel 3. Hasil Uji Sensoris Mie Goreng Instan

\begin{tabular}{lccccc}
\hline Parameter & \multicolumn{5}{c}{ Konsentrasi Tepung Asap } \\
\cline { 2 - 6 } Uji Sensoris & $\mathbf{0 \%}$ & $\mathbf{1 \%}$ & $\mathbf{2 \%}$ & $\mathbf{3 \%}$ & $\mathbf{4 \%}$ \\
\hline Rasa & 3,45 & 3,90 & 3,10 & 3,55 & 2,55 \\
Aroma & 3,15 & 3,70 & 3,00 & 3,05 & 2,10 \\
Kesukaan & 3,60 & 4,00 & 3,33 & 3,65 & 2,75 \\
\hline
\end{tabular}

Sifat lengket tersebut disebabkan jumlah asap cair yang ditambahkan pada campuran 4:1 sangat banyak sehingga tidak seluruh asap cair dapat diperangkap secara sempurna oleh maltodekstrin. Akibatnya tidak dapat dikeringkan pada suhu $70^{\circ} \mathrm{C}$ selama + 8 jam. Campuran tersebut mempunyai aroma/bau terdeteksi paling lemah yang disebabkan banyaknya senyawa volatil pada asap cair terperangkap sehingga sulit untuk menguap.

\section{Uji Sensoris}

Pada uji kesukaan ini digunakan 3 parameter uji, yaitu: rasa, aroma dan kesukaan secara keseluruhan yang diujikan pada 20 panelis tidak terlatih dengan produk mie goreng instan. Pengujian dilakukan dengan penambahan tepung asap cangkang sawit pada tiap konsentrasi sebanyak 3 tabur $(0,1 \mathrm{gr})$ dalam $134 \mathrm{gram}$ mie goreng instan. Pengujian dilakukan dengan skoring test rentang 1-5, dimana 1 untuk nilai sangat tidak disukai dan 5 untuk nilai sangat disukai. Hasil uji sensoris pada produk mie goreng instan terlihat pada Tabel 3.

Pada Tabel 3., terlihat bahwa dari berbagai variasi konsentrasi yang diujikan ternyata para panelis menyukai konsentrasi tepung asap $1 \%$. Untuk parameter rasa diperoleh rata-rata sebesar 3,90 artinya sebagian besar panelis suka terhadap mie goreng instan rasa asap. Hal tersebut juga terjadi pada paramter aroma dan kesukaan dengan nilai rata-rata berturut-turut 3,70 dan 4,00 . Yang artinya sebagian besar para panelis suka terhadap aroma dan tingkat kesukaan secara keseluruhan pada produk 
mie goreng rasa asap tersebut. Pada konsentrasi $1 \%$ terjadi keterpaduan antara citarasa dan aroma khas asap pada mie goreng instan sehingga disukai oleh konsumen.

Pada konsentrasi yang lebih tinggi, panelis cenderung tidak suka karena memberikan rasa asam dan pahit pada produk mie goreng instan. Sedangkan untuk produk dengan konsentrasi $0 \%$ (blangko), juga kurang disukai oleh panelis dibandingkan pada konsentrasi 1\%. Hal tersebut disebabkan aroma dan citarasa asap pada konsentrasi $1 \%$ terdeteksi lebih kuat dibandingkan blangko.

\section{Kajian Keamanan Pangan}

Penggunaan asap cair sebagai pengawet dan flavor pada makanan olahan sudah banyak dilakukan. Namun di dalam produk yang menggunakan asap masih sering dijumpai adanya senyawa polisiklik aromatik hidrokarbon (PAH) akibat pembakaran pada suhu tinggi. Salah satu jenis senyawa $\mathrm{PAH}$ yang paling banyak dijumpai adalah benzo( $\alpha$ )pyrene. Senyawa ini sangat berbahaya terutama karena sifatnya yang karsınogenik dan telah dinyatakan sebagai indikator kontaminasi PAH dalam makanan.

Mengingat kadar benzo( $\alpha)$ pyrene yang diperbolehkan dalam asap cair sebesar 0,1 ppm dan dalam bahan makanan sebesar 0,03ppb ( $\mu \mathrm{gr} / \mathrm{kg})(\mathrm{ku}, 1995)$, maka dalam $1 \mathrm{gr}$ tepung asap yang digunakan sebagai base (3:1) diperbolehkan maksimum mengandung 0,05 ugr benzo( $\alpha$ pyrene atau $50 \mathrm{ppb}$. Kemudian untuk 0,1 gr tepung asap $1 \%$ yang ditambahkan pada mie goreng instan dengan berat $134 \mathrm{gr}$ diperbolehkan mengandung $0,004 \mu \mathrm{gr}$ benzo $(\alpha)$ pyrene atau $40 \mathrm{ppb}$.

\section{KESIMPULAN}

Produksi asap cair cangkang sawit optimum diperoleh apabila kadar air bahan $17,75 \%$ selama 74,57 menit pada suhu $499,3^{\circ} \mathrm{C}$ dengan kandungan fenol, karbonil dan asam masing-masing sebesar 2,22 ; 2,13 dan $12,34(\%)$.

Produksi tepung asap yang disukai konsumen diperoleh dengan campuran redestilat asap cair dan maltodekstrin adalah 1:1. Dan setelah diuji sensoris pada mie goreng instan yang diproleh konsentrasi tepung asap cair sebesar $1 \%$.

\section{DAFTAR PUSTAKA}

Darmadji, P. (1995). Produksi asap cair dan sifat fungsionalnya [Laporan Penelitian]. Yogyakarta: Fakultas Teknologi Pertani-an, Universitas Gadjah Mada.

Demirbas, A. (2017). Higher heating values of lignin types from wood and non-wood lignocellulosic biomasses. Energy Sources, Part A: Recovery, Utilization, and Environmental Effects, 39(6), 592598.

Girard, J. P. (1992). Technology of meat and meat products. Ellis Horwood.

Hardiyanti R., Falah, M A F., Wijanarti, S., 2019. Metode Pengujian Sensoris Bahan Pangan, Sekolah Vokasi Universitas Gadjah Mada ,Yogyakarta.

Husbands, A., \& Cranford, S. (2019). A material perspective of wood, smoke, and BBQ. Matter, 1(5), 1092-1095.

Kurniawan, E. W., Amirta, R., Budiarso, E., Arung, E. T., (2019). Optimization of Temperature and Time Pyrolysis from White Charcoal Briquette Production of Wasted Oil Palm Shell and Acacia Bark With RSM Method. Russian Journal of Agricultural and Socio-Economic Sciences. $95.96-170$. 10.18551/rjoas.2019-11.21.

Kurniawan, E. W., Amirta, R., Budiarso, E., \& Arung, E. T. (2017). Mixing of Acacia Bark and Palm Shells to Increase Caloric Value of Palm Shells Arang putih (white charcoal) Briquette. In AIP Conference Proceedings (Vol. 1854, No. 1, p. 020021). AIP Publishing LLC. https://doi.org/10.1063/1.4985412

Kurniawan, E. W. (2008). Optimasi Produksi White Charcoal dari Arang Limbah Cangkang Kelapa Sawit, Tesis, Universitas Gadjah Mada, Yogyakarta.

Lewandowski, W. M., Ryms, M., \& Kosakowski, W. (2020). Thermal biomass conversion: A review. Processes,8(5),516.doi:10.3390/pr8050 516

Pszczola, D. E. (1995). Tour highlights production and uses of smoke-based flavors. Food (Chicago), 49(1), 70-74. 
BSN, 1995. SNI 06-3730-1995 Arang Aktif, Badan Standarisasi Nasional, Jakarta

Sudarmadji, S., Suhardi, B. Haryono, 2007. Analisa Bahan Makanan dan Hasil Pertanian, Liberty, Yogyakarta.

Speight, J. G. (2015). Handbook of coal analysis. John Wiley \& Sons, 364 page

Tomczyk, A., Sokołowska, Z., \& Boguta, P. (2020). Biochar Physicochemical Properties: Pyrolysis Temperature and
Feedstock Kind Effects. Reviews in Environmental Science and Bio/Technology, 19(1), 191-215. DOI: 10.1007/s11157-020-09523-3

Tranggono, Suhardi, Setiaji, Darmadji, Supranto dan Sudarmanto, 1996. Identifikasi Asap Cair dari Berbagai Jenis Kayu dan Tempurung Kelapa, Jurnal IImu \& Teknologi Pangan, I (2) : 15-24. 